\title{
Young Planted Jack Pine as a Seed Source for Supplementary Natural Regeneration
}

\author{
R. F. Sutton \\ Department of the Environment \\ Canadian Forestry Service \\ Great Lakes Forest Research Centre \\ Sault Ste. Marie, Ontario \\ P6A 5M7
}

During the course of artificial regeneration studies in Fawn Township, Ontario $\left(47^{\circ} 38^{\prime} \mathrm{N}, 82^{\circ} 29^{\prime} \mathrm{W}\right)$, newly germinated seedlings of jack pine (Pinus banksiana Lamb.) were observed casually every year from 1971 to the present time on a 1970 jack pine cutover, parts of which were planted to jack pine by Reynolds/Lowther/Beloit machine in 1971,1972 , and 1973 . Newly germinated natural seedlings were found in all parts of the planted cutover, not just along margins adjacent to uncut reserves. These seedlings probably outnumber the planted trees, although sampling was not done to determine this.

Up to 1973, it was obvious that many of the natural seedlings originated from seed released from cones remaining on the site after harvesting (Fig. 1). Thereafter, delayed germination was casually invoked to explain the continued ap-. pearance of new seedlings.

The possibility that new seedlings have continued to originate from seed from residual cones seems remote, for, whereas seedlings were commonly associated with cones (sometimes attached to slash, sometimes not) in the first few years after harvesting, seedlings and old cones have seldom, if ever, been observed in this relationship since then. Moreover, residual cones five or more years after harvesting do not appear to have much potential for natural regeneration, although this would have to be tested by experiment. There appears to be nothing in the literature on this point or on the duration of delayed germination. Nevertheless, although there is little doubt that some seed of certain species, including jack pine, may take two years or perhaps more to germinate in the field, the chances of germination after five or more years would seem very slight.

By 1976, after stem sectioning had shown that new germination was occurring year after year, a closer look at the situation seemed warranted.

Of two study plots, one $\left(350 \mathrm{~m}^{2}\right)$ was located in the 1971 plantation, the other $\left(700 \mathrm{~m}^{2}\right)$ in the 1972 plantation. Both plots were more than $300 \mathrm{~m}$ from a mature jack pine seed source. In the study areas, as in the rest of the plantation, cones were found on many of the planted trees (Table 1) as well as on some of the natural regeneration of similar vintage: $20 \%$ of the 5 -year-old trees and more than $50 \%$ of the 6 -year-old trees were bearing cones.

In the study area, as over much of its range, jack pine has serotinous cones, but, even where serotiny is normal, every year it is usual for some cones to open in mature jack pine, especially on the sunny side of the crown (Fowells 1965). Though not measured in the present study, air temperatures on sunny days and hence, presumably, cone temperatures, usually increase greatly with increasing proximity to the ground surface, so that the cones on young trees might be expected to open more readily than those on mature trees.

1 now the Petawawa National Forestry Institute
In the trees sampled in the present study $5 \%$ of the 5 -yearold trees and $33 \%$ of the 6 -year-old trees were found to be bearing open cones.

The conebearing trees, on average, were taller and had greater height increments for the years 1975 and 1976 than the non-conebearing trees, but the differences were statistically insignificant.

Cone production in young jack pine is common according to Fowells (1965), who cited Ellis (1911) and Sterrett (1920) to support the statement that seed production normally begins at 5 to 10 years of age in open-grown trees and at 10 to 25 years of age in stands. Cone and seed production in young plantations seem not to have been quantified in the literature.

The 46 conebearing trees yielded a total of 141 sound cones (and a further 22 small or otherwise defective cones)

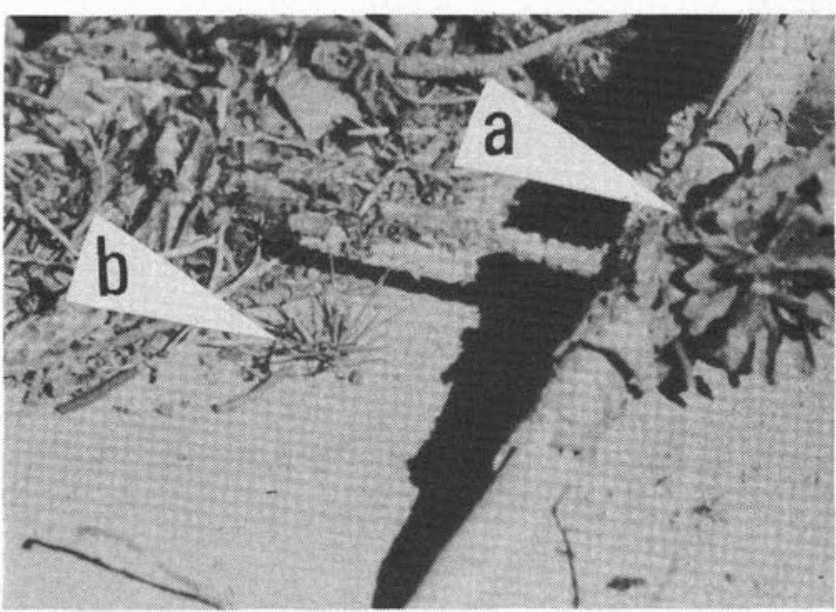

Fig. 1. Jack pine cone (a) and seedling (b) photographed in 1973 in furrow created by machine planting in 1971, Fawn Township, Ont.

Table 1. Occurrence of conebearing trees in samples of 6- and 5-year-old jack pine outplants, Fawn Township, Ontario, October 1976.

\begin{tabular}{lccc}
\hline $\begin{array}{l}\text { Year of } \\
\text { planting }\end{array}$ & $\begin{array}{c}\text { Trees } \\
\text { in } \\
\text { sample } \\
\text { (no.) }\end{array}$ & $\begin{array}{c}\text { Trees } \\
\text { bearing } \\
\text { cones } \\
(\%)\end{array}$ & $\begin{array}{c}\text { Trees } \\
\text { bearing } \\
\text { open } \\
\text { cones } \\
(\%)\end{array}$ \\
\hline 1971 & 43 & 53 & 33 \\
1972 & 101 & 20 & 5 \\
\hline
\end{tabular}


that contained a total of 1184 filled, 625 empty, and 21 damaged seeds as determined at the National Tree Centre at Petawawa Forest Experiment Station1, Chalk River, Ontario (B.S.P. Wang, 1977, personal communication).

Most conebearing trees carried only one cone. Occasional trees had relatively heavy cone crops, e.g., 21 cones in one instance. The percentage germination for filled seeds differed little between the 21 -cone tree $(82.3 \%)$ and the rest $(85.1 \%)$, but there were eight times more filled seeds per cone from the 21-cone tree, comparable with Sterling's (1903) determinations, than in the rest, in which there were only four seeds per cone.

The seed and cone production in these young plantations are small compared with those of mature stands where one mature tree may produce up to 1200 cones in one year (Ellis 1911). Nevertheless, the seed produced in very young stands may be used to silvicultural advantage.

Thus, an area could be regenerated to jack.pine in a twostage operation involving an initial planting of widely but regularly spaced trees that, beginning a few years later with the onset of seed production in the outplanted trees, will be supplemented by natural regeneration.

A basic minimum stocking would be assured by the planted trees. In this initial planting, the number of trees per unit area would be rather small, perhaps $400 /$ ha (at a spacing of $5 \mathrm{~m} \times 5 \mathrm{~m}$ ) to $625 / \mathrm{ha}$ (at $4 \mathrm{~m} \times 4 \mathrm{~m}$ ), so that planting costs would be relatively low. Also, planted trees could be expected to escape those losses (often approaching $10 \%$ ) incurred by burial under slash or soil when succeeding passes of a planting machine are made at closer spacing. The widely spaced initial planting would seem to offer an ideal outlet for efficient use of improved planting stock.

The supplementary natural regeneration, in addition to its improved genetic potential, would develop natural root systems which would surely increase stand stability compared to that of stands formed wholly by planting.

While the proposed system would be most applicable to burned or cutover jack pine sites lacking regeneration and seed source, the genetic benefits could be maximized by ridding a site of existing regeneration (by site preparation either before planting or before seedfall), thereby leaving the site to be occupied by improved outplants and their progeny.

\section{Acknowledgements}

The assistance of Mr. B. S. P. Wang and Mr. B. Haddon of Petawawa National Forestry Institute is warmly appreciated.

\section{References}

Ellis, L. M. 1911. Some notes on jack pine (Pinus divaricata) in western Ontario. For. Quart. 9:1-14.

Fowells, H. A. 1965. Silvics of forest trees of the United States. USDA For. Serv., Agric. Handb. 271, 762 p.

Sterling, E. A. 1903. Collecting jack pine seed. For. and Irrig. (now Am. For ) 9:27-32

Sterrett, W. D. 1920. Jack pine. USDA Bull. 820, 42 p. 